\title{
PENGARUH PEMANFAATAN TEKNOLOGI INFORMASI DAN PENERAPAN SISTEM PENGENDALIAN INTERN PEMERINTAH TERHADAP KUALITAS LAPORAN KEUANGAN PEMERINTAH DAERAH KABUPATEN HALMAHERA UTARA
}

\author{
Restika Eklesia Mene ${ }^{1}$, Herman Karamoy ${ }^{2}$, Jessy D.L.Warongan ${ }^{3}$ \\ 1,2,3 Jurusan Akuntansi, Fakultas Ekonomi dan Bisnis, Universitas Sam Ratulangi, Jl. Kampus Bahu, Manado, \\ 95115, Indonesia \\ E-mail : eklesiamene04@gmail.com
}

\begin{abstract}
Autonomous region demanded the Government Areas to provide the best service to the community. One form of such services is to provide financial information that is transparent and accountable. Accountability can be realized through local government financial reports are reliable in order to be trusted by users. The presence of finance report audit results areas that still require refinement exhortations continuously. Based on the Government Regulation Number 71 Year 2010, the quality of the financial report of the Central Government and regions must meet the qualitative characteristics, namely: relavan, reliably, understandable and comparable. This research aims to know the influence of the utilization of information technology and systems of internal control of financial reporting to the quality of government local government North Halmahera Regency as the sample. This research uses a quantitative approach, using primary data, the data collection was done by disseminating a questionnaire to all employees on the employees of the financial manager of the 28 units of Work Device area (SKPD) North Halmahera Regency by the number of respondents 60 people. Data analysis using the method of multiple regression analysis statistics. The results of hypothesis testing showed that the utilization of information technology and systems of internal control of the Government a positive and significant effect of the quality of the financial report of the local Government District of North Halmahera.

Keywords: quality of the financial report of the Government of the region, the utilization of information technology and Government internal control Systems
\end{abstract}

\section{PENDAHULUAN}

Seiring perkembangan Akuntansi Sektor Publik di Indonesia, maka kebutuhan akan akuntabilitas sebagai wujud pertanggungjawaban kepada masyarakat atas kinerja pemerintah menjadi suatu tuntutan yang umum. Dalam PP No 8 tahun 2006 telah menjelaskan tentang pelaporan keuangan dan kinerja instansi pemerintah. Laporan keuangan dan kinerja instansi pemerintah daerah ini menggambarkan output atau hasil dari kegiatan yang hendak atau telah dicapai sehubungan dengan penggunaan anggaran dengan kuantitas dan kualitas terukur sehingga dapat menjelaskan kinerja dan tanggungjawab pengelolaan anggaran keuangan selama periode tertentu.

Pengguna Laporan Keuangan Pemerintah yang dihasilkan harus memenuhi prinsipprinsip tepat waktu dan posisi keuangan dan transaksi-transaksi yang dilakukan oleh suatu entitas pelaporan. Dalam menyajikan Laporan Keuangan Pemerintah harus disusun dengan mengikuti Standar Akuntansi Pemerintahan sesuai dengan Peraturan Pemerintah Nomor 71 Tahun 2010. Informasi yang terdapat dalam Laporan Keuangan Pemerintah Daerah (LKPD) harus memenuhi beberapa karakteristik kualitatif yang sebagaimana disyaratkan Standar Akuntansi Pemerintahan yaitu Relevan, Andal, Dapat Dibandingkan dan Dapat Dipahami.

Untuk dapat memenuhi karakteristik kualitatif tersebut, maka pengelolaan keuangan di pemerintah daerah tidak terlepas dari peran pegawai yang mengelola dan melakukan 
pelaporan keuangan. maka pekerjaan tersebut akan lebih mudah untuk dilaksanakan. Dengan adanya Penerapan Sistem Pengendalian Intern Pemerintah (SPIP), Sistem Pengendalian Intern Pemerintah (SPIP) terdiri dari beberapa unsur, diantaranya :

1. Lingkungan Pengendalian,

2. Penilaian Resiko,

3. Informasi dan Komunikasi,

4. Pemantauan

Sebagai metode untuk dapat mengawasi dan memberikan keyakinan tercapainya tujuan suatu organisasi dalam rangka memberikan keyakinan yang memadai bahwa kegiatan telah dilaksanakan sesuai dengan tolak ukur yang telah dilaksanakan secara efektif dan efisien dalam mewujudkan tata kepemerintahan yang baik disebut dengan Pengawasan Intern, sehingga hal-hal yang telah direncanakan dapat terlaksana. Untuk menciptakan integrasi kebijakan pengawasan penyelenggaraan pemerintahan daerah, maka pembinaan Aparat Pengawas Internal Pemerintah (APIP) harus dilakukan secara terus-menerus (series of actions and ongoing basis). Disamping itu, diperlukan perubahan pola pikir (mind set) Aparat Pengawas Internal Pemerintah sebagai pemberi peringatan dini (early warning) terhadap temuan pelanggaran atau penyimpangan yang berindikasi korupsi, kolusi, dan nepotisme (Armando, 2013:9).

Selain dengan adanya Aparat Pengawas Internal Pemerintah (APIP) audit Laporan Keuangan Pemerintah Daerah (LKPD) juga dilakukan oleh Badan Pengawas Keuangan (BPK) sebagai auditor eksternal pemerintah sesuai dengan amanat Undang-Undang Nomor 15 Tahun 2004, diberika kewenangan melakukan pemerikasaan keuangan atas laporan keuangan pemerintah pusat dan pemerintah daerah berdasarkan standar pemerikasaan keungan negara dalam rangka memberikan opini tentang tingkat kewajaran informasi yang disajikan dalam laporan keungan pemrintah pusat dan daerah. Didalam penjelasan UndangUndang Nomor 15 Tahun 2004 yang dimaksud opini adalah pernyataan profesional pemeriksa mengenai kewajaran informasi keuangan yang disajikan dalam laporan keuangan yang didasarkan pada kriteria sebagai berikut :

a. kesesuaian dengan standar akuntansi pemerintahan,

b. kecukupan pengungkapan (adequate disclosures),

c. kepatuhan terhadap peraturan perundang-undangan, dan

d. efektivitas sistem pengendalian intern.

Opini yang diberikan atas suatu laporan keuangan pemerintah daerah merupakan gambaran kualitas akuntabilitas pengelolaan keuangan daerah, adanya kenaikan opini merupakan adanya perbaikan akuntabilitas dalam penyajian laporan keuangan sesuai dengan standar akuntansi pemerintahan yang berlaku. Opini tidak memberikan pendapat (TMP), artinya auditor tidak dapat memberikan pendapat atas laporan keuangan yang diperiksa karena dua alasan, yaitu auditor terganggu independensinya dan auditor dibatasi untuk mengakses data tertentu. Opini wajar dengan pengecualian (WDP), bahwa laporan keuangan yang diperiksa sebagian besar pos dalam laporan keuangan, posisi keuangan, hasil usaha dan arus kas entitas tersebut telah disajikan secara wajar terbebas dari salah saji material dan sesuai dengan prinsip akuntansi yang berlaku umum di Indonesia, kecuali untuk dampak hal-hal yang berhubungan dengan yang dikecualikan untuk pos-pos tertentu disajikan secara tidak wajar. Opini wajar tanpa pengecualian (WTP) adalah jika laporan keuangan dianggap memberikan informasi yang bebas dari salah saji material. Opini WTP dengan paragraf penjelasan ( WTP-DPP) auditor harus menambahkan suatu paragraf penjelasan dalam laporan audi. Ada beberapa keadaan yang menyebabkan ditambahkannya paragraf penjelasan. misalnya, tidak adanya konsisten penerapan prinsip akuntansi, adanya keraguan tentang kelangsungan hidup lembaga pengelola keuangan. 
Objek dalam penelitian ini yaitu kabupanten Halmahera utara yang merupakan salah satu kabupaten di provinsi Maluku Utara. Di Kabupaten Halmahera Utara opini atas hasil pemeriksaan yang diberikan oleh Badan Pemeriksa Keuangan (BPK) terhadap laporan keuangan pemerintah daerah Kabupaten Halamhera Utara pada tahun anggaran 2014-2015 yaitu wajar dengan pengecualian (WDP), sendangkan pada tahun 2016 telah mengalami kenaikan tingkat opini yaitu oponi wajar tanpa pengecualian (WTP) yang berarti adanya perbaikan akuntabilitas dan transparansi penyajian laporan keuangan sesuai dengan standar akuntansi pemerintahan yang berlaku. Adapun hasil penelitiannya menyebutkan bahwa kualitas sumber daya manusia dan pemanfaatan teknologi informasi berpengaruh signifikan terhadap keterandalan dan ketepatwaktuan, serta pengendalian intern akuntansi berpengaruh signifikan terhadap keterandalan. Hal ini menunjukkan bahwa semakin baik kapasitas sumber daya manusia, pemanfaatan teknologi informasi dan pengendalian intern pemerintah maka semakin baik pula kualitas laporan keuangan pemerintah daerah.

\section{TINJAUAN PUSTAKA}

\subsection{Pengertian Akuntansi}

Menurut American Institute of Certified Public Accounting (AICPA) sebagaimana yang ditulis oleh Syakur (2015:2) mendefinisikan akuntansi sebagai suatu seni pencatatan, penggolongan, peringkas yang tepat dan dinyatakan dalam satuan mata uang menggunakan cara tertentu dalam ukuran moneter transaksi dan kejadian- kejadian yang umumnya bersifat keuangan dan termasuk menafsirkan hasil- hasilnya. Menurut Reeve, dkk (2012: 9), Akuntansi adalah suatu sistem informasi yang menyediakan laporan untuk pemangku kepentingan mengenai aktivitas dan kondisi ekonomi perusahaan. Akuntansi adalah proses pencatatan, pengklasifikasian dan pengelompokkan semua transaksi yang terjadi dalam bentuk laporan keuangan untuk memberikan informasi kepada perusahaaan dan kepada pihak yang membutuhkan.

\subsection{Standar Akuntansi Pemerintahan}

Menurut Peraturan Pemerintrah RI No. 71 Tahuh 2010, SAP merupakan prinsipprinsip akuntansi yang diterapkan dalam menyusun dan menyajikan Laporan Keuangan pemerintah. SAP yang digunakan saat ini adalah Peraturan Pemerintah No. 24 Tahun 2005 yang menggunakan basis kas dan harus segera diganti dengan basis akrual Peraturan Pemerintah No. 71 Tahun 2010 yang dianggap lebih akuntabel dan lebih mencerminkan prinsip Good Government Govenrnancel Good Public Governance.

\subsection{Laporan Keuangan Pemerintah Daerah}

Laporan Keuangan yang disajikan Pemerintah Daerah dinilai berkualitas apabila memenuhi kriteria sebagai berikut: (1) relevan; (2) andal; (3) dapat dibandingkan; dan (4) dapat dipahami. (Mahmudi, 2016:11).

\subsection{Teknologi Informasi}

Untuk mengetahui terminologi teknologi informasi, terlebih dahulu kita memahami pengertian teknologi dan informasi itu sendiri. Teknologi yaitu sistem umtuk melakukan sesuatu dalam memenuhi kebutuhan manusia dengan bantuan alat dan akal (Hardware dan Software) seolah-olah memperpanjang, memperkuat, atau membuat lebih ampuh anggota tubuh, panca indera dan otak manusia, sedangkan informasi adalah hasil pemrosesan, manipulasi, dan pengorganisasian atau penataan dari sekedar kelompok data yang mempunyai nilai pengetahuan bagi penggunanya (Sutabri 2014:2). (Afiah dan Nuryanto, 2013: 159) Pemerintah perlu mengoptimalkan penggunaan teknologi informasi canggih untuk sistem informasi manajemen jaringan bangunan dan proses kerja yang memungkinkan government untuk bekerja secara terpadu dengan menyederhanakan akses antar unit. 


\subsection{Sistem Pengendalian Intern}

Menurut Numalia Hasanah dan Achmad Fauzi (2016: 180), Sistem Pengendalian intern adalah proses yang integral pada tindakan dan kegiatan yang dilakukan secara terus menerus oleh pimpinan dan seluruh pegawai untuk memberikan keyakinan memadai atas tercapainya tujuan organisasi melelui kegiatan yang efektif dan efisien, keandalan pelaporan keuangan, pengamatan aset negara, dan ketaatan terhadap peraturan perundang-undangan.

\subsection{Sistem Pengendalian Intern Pemerintah}

Pemerintah telah mengeluarkan peraturan sebagai ketentuan penerapan pengendalian intern pada instansi pemerintah, yaitu Peraturan Pemerintah Nomor 60 Tahun 2008 tentang Sistem Pengendalian Intern Pemerintah (SPIP). SPIP terdiri dari lima unsur, yaitu lingkungan pengendalian, penilaian risiko, kegiatan pengendalian, informasi dan komunikasi, serta pemantauan (Suwanda dan Dailibas 2013: 5).

\subsection{Hipotesis Penelitian}

Hipotesis yang diambil dalam penelitian ini terdiri dari dua hipotesis, yaitu sebagai berikut :

H1 : Pemanfaatan teknologi informasi berpengaruh positif dan signifikan terhadap kualitasLaporan Keuangan Pemerintah Daerah

$\mathrm{H}_{2}$ : Penerapan sistem pengendalian intern pemerintah berpengaruh positif dan signifikan terhadap Kualitas Laporan Keuangan Pemerintah Daerah

\section{METODE PENELITIAN}

\subsection{Jenis dan Sumber Data}

Jenis metode penelitian ini merupakan jenis pendekatan kuantitatif. Sumber data dari penelitian ini adalah data primer, sumber data yang langsung memberikan data kepada pengumpul data. data yang digunakan adalah dengan mendatangi secara langsung kantor SKPD Kabupaten Halmahera Utara dan memberikan kuesioner yang berisi pertanyaan terstruktur yang ditujukan kepada responden, Kuesioner yang dibagikan yaitu pada pegawai pengelola subbagian keuangan yang melaksanakan fungsi akuntansi/tata usaha keuangan SKPD.

\subsection{Sampel dan Teknik Pengambilan Sampel}

Sampel adalah bagian dari jumlah dan karakteristik yang dimiliki oleh populasi, menurut sugiyono (2013: 118). Dalam penelitian ini sampel menggunakan metode purposive sampling, dengan kriteria responden adalah Kepala Subbagian Keuangan dan Bendahara (penerimaan dan pengeluaran), dan sampel dalam penilitian ini adalah 60 sampel yang diambil.

\section{3. $\quad$ Metode Analisis}

Model analisis ini dipilih karena penelitian ini dirancang untuk meneliti variabel bebas yang berpengaruh terhadap variabel terikat. Pengujian regresi linear berganda di awali dengan Uji Asumsi Klasik. Dengan adanya uji asumsi klasik Uji Normalitas, Uji Multikolinearitas, Uji Heteroskedastisitas, agar pengujian ini diperoleh dan dapat dipertanggungjawabkan, sebelum melakukan Uji Regresi dan Uji Hipotesis.

\section{HASIL ANALISIS DAN PEMBAHASAN}

\subsection{Hasil Analisis}

\subsubsection{Uji Asumsi Klasik}

Sebelum melakukan analisis regresi linier berganda, data yang diuji terlebih dahulu dengan uji asumsi klasik untuk melakukan pengujian. Uji asumsi klasik yang dipakai yaitu Uji Normalitas, Uji Multikolinearitas, dan Uji Hetoroskadektisitas. Berikut adalah hasil uji asumsi klasik dalam penelitian ini. 
a. Uji Normaliatas

Untuk mengetahui normalitas dari distribusi data dilakukan dengan uji one sample kolmogorov smirnov test. Uji normalitas data dilakukan untuk melihat apakah data dapat terdistribusi dengan normal atau tidak. Dalam penelitian ini, pengujian normalitas dilakukan berdasarkan uji Kolmogorov-Smirnov. Uji normalitas bertujuan untuk menguji apakah dalam model regresi, variabel bebas dan variabel terikat keduanya memiliki distribusi normal atau tidak (Ghozali, 2013).

\section{One-Sample Kolmogorov-Smirnov Test}

\begin{tabular}{|c|c|c|c|c|}
\hline & & Kualitas_Laporan_Keuangan & Pemanfaatan_Teknologi_Informasi & $\begin{array}{c}\text { Sistim_Pengendalian } \\
\text { Intern }\end{array}$ \\
\hline \multicolumn{2}{|l|}{$\mathrm{N}$} & 60 & 60 & 60 \\
\hline \multirow{4}{*}{$\begin{array}{c}\text { Normal } \\
\text { Parameters }{ }^{\mathrm{a}, \mathrm{b}} \\
\text { Most Extreme } \\
\text { Differences }\end{array}$} & Mean & 71.7167 & 38.3167 & 64.5167 \\
\hline & $\begin{array}{c}\text { Std. } \\
\text { Deviation }\end{array}$ & 7.43125 & 3.61490 & 6.84821 \\
\hline & Absolute & 108 & .123 & .070 \\
\hline & Positive & .108 & .123 & .063 \\
\hline & Negative & -.070 & -.086 & -.070 \\
\hline Test Stat & & .108 & .123 & .070 \\
\hline Asymp. Sig. & -tailed) & $.079^{\mathrm{c}}$ & $.025^{\mathrm{c}}$ & $.200^{\mathrm{c}, \mathrm{d}}$ \\
\hline
\end{tabular}

Sumber :Data Olahan Menggunakan Program SPSS 23.0

Berdasarkan hasil di atas uji normalitas Kolmogorov-Smirnov Test jika hasil probalitas angka signifikansi $>0,05$ maka data normal dan jika angka signifikansi $<0,05$ maka data tidak normal, maka berdasarkan hasil probalitas angka signifikansi (sig) 0,200 > 0,05 berarti data residual berdistribusi normal.

b. Uji Multikolinearitas

Uji multikolinieritas dilakukan dengan menganalisa korelasi antar variabel independen pada nilai Tolerance value 0.10 dan nilai Variance Inflation Factor (VIF) dalam collinearity statistics 10 (Ghozali, 2013). Bisa dilihat dari nilai VIF>10 dan nilai Tolerance < 0.10, maka tejadi multikolinearitas. Hasil pengujian multikolinearitas dapat dilihat pada tabel berikut:

Coefficients ${ }^{\mathrm{a}}$

\begin{tabular}{|c|c|c|c|c|c|c|c|c|}
\hline \multirow{2}{*}{\multicolumn{2}{|c|}{ Model }} & \multicolumn{2}{|c|}{$\begin{array}{c}\text { Unstandardized } \\
\text { Coefficients }\end{array}$} & \multirow{2}{*}{$\begin{array}{c}\text { Standardized } \\
\text { Coefficients } \\
\text { Beta }\end{array}$} & \multirow[b]{2}{*}{$\mathrm{T}$} & \multirow[b]{2}{*}{ Sig. } & \multicolumn{2}{|c|}{ Collinearity Statistics } \\
\hline & & B & $\begin{array}{l}\text { Std. } \\
\text { Error }\end{array}$ & & & & Tolerance & VIF \\
\hline \multirow[t]{3}{*}{1} & (Constant) & 7.499 & 7.226 & & 1.038 & .304 & & \\
\hline & Pemanfaatan_Teknologi_Informasi & .555 & .194 & .270 & 2.857 & .006 & .769 & 1.301 \\
\hline & & .666 & .103 & .613 & 6.491 & .000 & .769 & 1.301 \\
\hline
\end{tabular}

Sumber :Data Olahan Menggunakan Program SPSS 23.0

Berdasarkan pengolahan data dan hasil perhitungan nilai Tolerance dan VIF diatas dapat simpulkan bahwa variabel independen memiliki nilai Tolerance $>0,10$ dan nilai $V I F<$ 10, sehingga tidak terjadi multikolinieritas.

c. Uji Heterokedastisitas

Uji heterokesdastisitas bertujuan menguji apakah dalam model regresi terjadi ketidaksamaan varians dari residual satu pengamatan kepengamatan lain. Uji heteroskedastisitas yang digunakan oleh peneliti adalah menggunakan uji Part. Uji ini ditempuh dengan melakukan regresi terhadap nilai logaritma dari kuadrat residual (Ghozali, 2013). Model regresi dikatakan bebas dari heteroskedastisitas apabila signifikannya lebih besar dari $\alpha(5 \%)$. Hasil uji heretoskedastisitas dapat dilihat dalam tabel berikut: 


\begin{tabular}{|c|c|c|c|c|c|c|}
\hline \multicolumn{7}{|c|}{ Coefficients ${ }^{\mathrm{a}}$} \\
\hline \multirow{2}{*}{\multicolumn{2}{|c|}{ Model }} & \multicolumn{2}{|c|}{ Unstandardized Coefficients } & $\begin{array}{l}\text { Standardized } \\
\text { Coefficients }\end{array}$ & \multirow[b]{2}{*}{$\mathrm{T}$} & \multirow[b]{2}{*}{ Sig. } \\
\hline & & $\mathrm{B}$ & Std. Error & Beta & & \\
\hline 1 & (Constant) & -5.222 & 4.678 & & -1.116 & .269 \\
\hline & Pemanfaatan_Teknologi_Informasi & 0.106 & .126 & .123 & .840 & .404 \\
\hline & Sistem_Pengendalian_Intern_Pemerintah & .071 & .066 & .158 & 1.075 & .287 \\
\hline
\end{tabular}

Sumber :Data Olahan Menggunakan Program SPSS 23.0

Berdasarkan hasil pengujian heteroskedastisita diatas menunjukan bahwa probalitas atau taraf signifikansi masing-masing variabel independen $>0.05$, sehingga dapat dipastikan bahwa model tersebut tidak terjadi heteroskedastisitas.

\subsubsection{Uji Regresi Linear Berganda}

Koefisien ini diperoleh dengan cara memprediksi nilai variabel idependen dengan suatupersamaan (Ghozali, 2013). Model statistik yang digunakan peneliti untuk mengukur pengujian terhadap hipotesis ini adalah dengan menggunakan model regresi linear berganda. Hipotesis yang diajukan pada penelitian ini adalah dengan menggunakan pemanfaatan teknologi informasi dan penerapan sistem pengendalian intern pemerintah dan mempengaruhi secara positif kualitas laporan keuangan pemerintah daerah pada Satuan Kerja Perangkat Daerah Kabupaten Halmahera Utara. Hasil analisis regresi adalah berupa koefisien untuk masing-masing variabel independen.

Coefficients $^{\text {a }}$

\begin{tabular}{|c|c|c|c|c|c|}
\hline \multirow[b]{2}{*}{ Model } & \multicolumn{2}{|c|}{$\begin{array}{c}\text { Unstandardized } \\
\text { Coefficients } \\
\end{array}$} & \multirow{2}{*}{$\begin{array}{c}\text { Standardized } \\
\text { Coefficients }\end{array}$} & \multirow[b]{2}{*}{$\mathrm{T}$} & \multirow[b]{2}{*}{ Sig. } \\
\hline & $\mathrm{B}$ & Std. Error & & & \\
\hline (Constant) & 7.499 & 7.226 & & 1.038 & .304 \\
\hline Pemanfaatan_Teknologi_Informasi & .555 & .194 & .270 & 2.857 & .006 \\
\hline Sistem_Pengendalian_Intern_Pemerintah & .666 & .103 & .613 & 6.491 & .000 \\
\hline
\end{tabular}

Sumber :Data Olahan Menggunakan Program SPSS 23.0

Dari hasil uji regresi linear berganda dapat diperoleh persamaan regresi linier berganda sebagai berikut.

$\mathrm{Y}=\alpha+\beta 1 \mathrm{X} 1+\beta 2 \mathrm{X} 2+\mathrm{e} \ldots \ldots \ldots \ldots$

$\mathrm{Y}=7.449+0.555(\mathrm{X} 1)+0.666(\mathrm{X} 2) \ldots$

Keterangan:

Y : Kualitas Laporan Keuangan

X1 : Pemanfaatan Teknologi Informasi

X2 : Penerapan Sistem Pengedalian Intern

$\alpha \quad$ : Konstanta

$\beta \quad$ : Koefisien regresi

e :Standart error

Berdasarkan hasil perhitungan dan pengelolaan data dengan menggunakan bantuan program SPSS Version 23.0, maka hasil perhitungan analisis regresi linier berganda dapat dilihat dalam table 4.8 diatas. Dapat di lihat hasil konstanta 7.449 memberikan pengertian bahwa jika Pemanfaatan Teknologi informasi (X1), Penerapan Sistem Pengendalian Intern Pemerintah (X2) konstan nol (0) maka besarnya tingkat Kualitas Laporan Keuangan Pemerintah Daerah sebesar 7.449. Sedangkan $\beta 1$ yang merupakan koefisien regresi dan 
variabel X1 sebesar 0.555 yang mempunyai arti bahwa semakin menigkat Pemanfaatan Tekonologi Informasi, maka latar belakang Pemanfaatan Teknologi Informasi terhadap Kualitas Laporan Keuangan Pemerintah Daerah, maka besarnya Kualitas Laporan Keuangan Pemerintah Daerah akan mengalami peningkatan sebesar 0.555 satuan dengan asumsi variabel lainnya tetap atau kontantan. Nilai $\beta 2$ yang merupakan koefisien regresi dari variabel X2 sebesar 0.666 yang mempunyai arti bahwa jika Penerapan Sistem Pengendalian Intern Pemerintah mengalami peningkatan, maka Penerapan Sistem Pengandalian Intern Pemerintah terhadap Kualitas Laporan Keunagan Pemerintah Daerah, maka akan cenderung terjadi peningkatan Kualitas Laporan Keuangan Pemerintah Daerah sebesar 0.666 satuan dengan asumsi variabel lain tetap atau konstan. Dengan demikian dapat diketahui bahwa Pemanfaatan teknologi Informasi dan Penerapan Sistem Pengendalian Intern mengalami peningkatan, maka besarnya nilai Kualiatas Laporan Keuangan Pemerintah Daerah juga mengalami peningktan. Sebaliknya jika Pemanfaatan Teknologi Informasi dan Penerapan Sistem Pengendalian Intern akan ikut mengalami penurunan.

Dengan melihat hasil tabel diatas dapat ditarik kesimpulan bahwa terdapat hubungan yang baik dan searah antara variabel bebas (X) dengan variabel terikat (Y), dimana angka koefisien regresi yang diperoleh menunjukan angka positif atau hubungan yang searah hal ini dibuktikan dengan sig. $<a$, atau $0.000<0.05$ ini berarti kedua variabel memiliki hubungan positif.

\subsubsection{Koefisien Determinasi $\left(\mathbf{R}^{2}\right)$}

Koefisien Determinasi (R2) digunakan untuk mengetahui seberapa jauh kemampuan pengaruh pemanfaatan teknologi informasi dan penerapan sitem pengendalian intern terhadap kualitas laporan keuangan pemerintah daerah sdalam menerangkan variansi variabel dependen. Dalam penelitian ini menggunakan nilai asjusted R Square untuk mengetahui nilai $R 2$. Koefisien determinasi $\left(\mathrm{R}^{2}\right)$ bertujuan untuk mengukur seberapa besar. Dari hasil uji regresi linear berganda diperoleh hasil sebagai berikut.

\begin{tabular}{|c|r|r|r|r|}
\hline Model & R & R Square & Adjusted R Square & Std. Error of the Estimate \\
\hline 1 & $.780^{\mathrm{a}}$ & .609 & .595 & 4.73038 \\
\hline
\end{tabular}

Sumber :Data Olahan Menggunakan Program SPSS 23.0

Berdasarkan tabel 4.9 hasil uji koefisien determinasi $\left(\mathrm{R}^{2}\right)$ Square dapat dilihat bahwa yang di peroleh nilai $\mathrm{R}$ adalah 0.609 atau $60.9 \%$. Hal ini menunjukan bahwa model regresi yang didapat mampu menjelaskan Pengaruh Pemanfaatan Teknologi Informasi dan Penerapan Sistem Pengendalian Intern Pemerintah secara simultan terhadap kualitas laporan keuangan $60.9 \%$ sendangkan sisanya $30.1 \%$ dipengaruhi oleh faktor atau variabel lain (dimana $\mathrm{R}^{2}$ merupakan koefisien determinasi ), yang tidak diteliti dalam penilitian.

\subsubsection{Uji Hipotesis}

a. Uji Statistik t (t-test)

Uji t digunakan untuk mengetahui pengaruh variabel bebas terhadap variabel terikat dan uji t digunakan untuk melihat pengaruh secara satu per satu atau secara parsial. Hasil pengujian parsial dapat dilihat pada tabel sehingga dapat disimpulkan bahwa : 


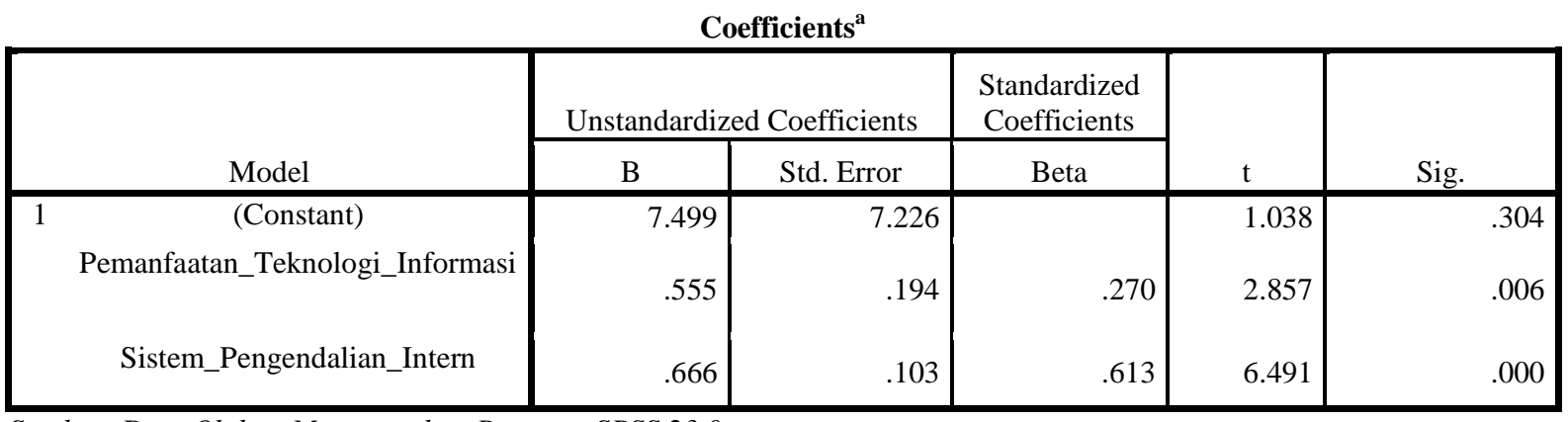

Sumber :Data Olahan Menggunakan Program SPSS 23.0

Berdasarkan tabel diatas yang telah di lakukan maka dapat diketahui hasil t-hitung untuk Pemanfaatan Teknologi Informasi $(X 1)=2.857$, Penerapan Sistem Pengendalian Intern Pemerintah $(\mathrm{X} 2)=6.491$ dan t-tabel 2,002 atau dapat dilihat $(\mathrm{X} 1)$ t-hitung sebesar $2.857>$ 2,002 yang berarti t-hitung > t-tabel dengan hasil signifikansi 0,006 $<0,05$ sehingga H1 diterima. Hal ini menunjukan bahwa pemanfaatan teknologi informasi berpengaruh positif dan signifikan terhadap kualitas laporan keuangan pemerintah daerah, dan (X2) t-hitung sebesar $6.491>2,002$ yang berarti t-hitung > t-tabel dengan hasil signifikansi 0,000 < 0,05, sehingga $\mathrm{H} 2$ diterima. Hal ini menunjukan bahwa penerapan sistem pengendalian intern pemerintah berpengaruh positif dan signifikan terhadap kualitas laporan keuangan pemerintah daerah. Berdasarkan perhitungan uji $t$ diketahui baha variabel-variabel independen Pemanfaatan Teknologi Informasi dan Penerapan system Pengendalian Intern Pemerintah berpengaruh positif dan signifikan terhadap variabel dependen, yaitu Kualitas Laporan Keuangan Pemerintah Daerah.

b. Uji F (Uji Simultan)

Uji F yaitu uji Anova yang merupakan uji untuk melihat bagaimana pengaruh semua variabel $\mathrm{X}$ secara bersama-sama terhadap variabel $\mathrm{Y}$, untuk menguji apakah modal regresi yang dibuat baik signifikan atau tidak signifikan. Uji $\mathrm{F}$ menunjukan tingkat signifikan $5 \%$ ( $a$ $=0,05)$.

\begin{tabular}{|c|c|c|c|c|c|c|}
\hline \multicolumn{7}{|c|}{ ANOVA $^{a}$} \\
\hline & Model & Sum of Squares & Df & Mean Square & $\mathrm{F}$ & Sig. \\
\hline 1 & Regression & 1982.721 & 2 & 991.360 & 44.304 & $.000^{\mathrm{b}}$ \\
\hline & Residual & 1275.462 & 57 & 22.377 & & \\
\hline & Total & 3258.183 & 59 & & & \\
\hline
\end{tabular}

Sumber :Data Olahan Menggunakan Program Spss 23.0

Dari hasil output tabel 4.11 di atas dapat dilihat uji $\mathrm{F}$ memperlihatkan F-hitung sebesar 44.304 dengan signifikan 0.000, Sendangkan F-tabel 13,16 yang berarti F-hitung > Ftabel $44.304>3.16$ dan nilai signifikan $0.000<0.05$, maka dapat disimpulkan bahwa H3 di terima yang berarti variabel $\mathrm{X} 1$ dan $\mathrm{X} 2$ secara simultan berpengaruh signifikan terhadap variabel Y, Berarti Pemanfaatn Teknologi Informasi dan Penerapan Sitem Pengendalian Intern berpengaruh Positif dan signifikan terhadap Kualitas Laporan Keuangan Pemerintah Daerah.

\subsection{Pembahasan}

Penilitian ini dilakukan pada Kantor Bupati Kabupaten Halmahera Utara dengan jumlah responden 60 orang, yang menjadi sampel dalam penilitian ini adalah pengelola keuangan (Kabag dan Bendehara) di SKPD yang didalamnya Dinas dan Badan Kabupaten maupun kota. Pada bagian ini penulis mencoba menganalisa dan membahas seberapa besar 
pengaruh variabel independen $(\mathrm{X})$ dan variabel dipenden $(\mathrm{Y})$, serta membahas keeratan hubungan variabel-variabel tersebut.

\section{Pengaruh Pemanfaatan Teknologi Informasi Terhadap Kualitas Laporan Keuangan Pemerintah Daerah}

Hasil pengujian hipotesis pertama menunjukkan bahwa pada pemanfaatan teknologi informasi nilai t sebesar 2.857dan t-tabel sebesar 2,002 dari Uji t menujukan nilai t-hitung > t-tabel hal ini berarti hipotesis Pemanfaatan Teknologi Informasi terhadap Kualitas Laporan Keuangan Pemerintah Daerah berpengaruh Positif dan signifikan. Artinya pemanfaatan teknologi informasi di Kabupaten Halmahera Utara sudah memadai. hal ini terlihat bahwa semakin baik pemanfaatan teknologi informasi, maka semakin baik pula kualitas laporan keuangan pemerintah daerah yang dihasilkan. teknologi informasi memiliki peranan yang penting dalam meningkatkan kualitas laporan keuangan pemerintah daerah pada Satuan Kerja Perangkat Daerah (SKPD) Kabupaten Halmahera Utara. Dalam penjelasan Peraturan Pemerintah No. 56 Tahun 2005 tentang Sistem Informasi Keuangan Daerah disebutkan bahwa untuk menindaklanjuti terselenggaranya proses pembangunan yang sejalan dengan prinsip tata kelola pemerintahan yang baik (good governance), pemerintah dan pemerintah daerah. Hal ini terwujudnya kualitas laporan keuangan pemerintah daerah tergantung pada kemajuan teknologi yang digunakan. Hasil penelitian ini mendukung penelitian yang dilakukan sebelumnya yaitu Nurillah (2014) dan maulidia et.al (2015), Menunjukkan bahwa pemanfaatan teknologi informasi berpengaruh signifikan terhadap kualitas laporan keuangan pemerintah daerah.

Hasil ini mengindikasikan bahwa pemanfaatan teknologi informasi telah sepenuhnya memberikan hasil yang diharapkan terutama dalam meningkatkan kualitas laporan keuangan, hal ini juga menunjukkan bahwa SKPD Kabupaten Halmahera Utara telah didukung teknologi baik software dan hardware dalam hal menjalankan kegiatan organisasinya.

\section{Pengaruh Penerapan Sistem Pengendalian Intern Pemerintah Terhadap Kualitas Laporan Keuangan Pemerintah Daerah}

Hasil pengujian hipotesis kedua menunjukkan bahwa pada Penerapan Sistem Pengendalian Intern Pemerintah (SPIP) nilai t sebesar 6.491 dan t-tabel sebesar 2,002 dari Uji $t$ menujukan nilai $t>t$-tabel hal ini berarti hipotesis Penerapan Sistem Pengendalian Intern Pemerintah (SPIP) terhadap Kualitas Laporan Keuangan berpengaruh positif dan signifikan. Penerapan Sistem Pengendalian Intern Pemerintah dimaksudkan dengan tujuan memberikan keyakinan yang memadai agar tercapainya pengelolaan yang efektif dan efisien berdasarkan pada Peraturan Pemerintah Nomor. 60/2008, antara lain: lingkungan pengendalian, penilaian resiko, kegiatan pengendalian, informasi dan komunikasi serta pemantauan. Dapat dilihat bahwa penerapan sistem pengendalian intern pemerintah berpengaruh positif dan signifikan terhadap kualitas laporan keuangan pemerintah daerah Kabupaten Halmahera Utara . Artinya bahwa, semakin baik pelaksanaan unsur Penerapan SPIP maka semakin baik pula Kualitas Laporan Keuangan pemerintah daerah yang dihasilkan.

Penerapan Sistem Pengendalian Intern Pemerintah (SPIP) ini adalah proses yang dirancang oleh manajemen untuk memberikan jaminan atau keyakinan yang memadai atas tercapainya tujuan organisasi melalui kegiatan yang efektif dan efisien. Penerapan Sistem Pengendalian Intern Pemerintah yang efektif akan melindungi organisasi dari kelemahan manusia, mengurangi kekeliruan dan penyimpangan yang akan terjadi, sehingga informasi yang dihasilkan dalam laporan keuangan dapat memenuhi karakteristik kualitatif laporan keuangan dan akan meningkatkan kepercayaan stakeholders. Berdasarkan data jawaban responden, rata-rata responden menjawab setuju untuk setiap indikator penilaian, Hal ini menunjukan bahwa Penerapan SPIP di Kabupaten Halmahera Utara sudah baik. Hasil penelitian ini sejalan dengan penelitian Soimah (2014) yang menyatakan bahwa Sistem 
Pengendalian Intern Pemerintah berpengaruh positif terhadap Kualitas Laporan Keuangan Pemerintah Daerah Kabupaten Bengkulu Utara.

\section{Pengaruh Pemanfaatan Teknoogi Informasi dan Penerapan Sistem Pengendalian Intern Pemerintah Terhadap Kualitas Laporan Keungan Pemerintah Daerah Kabupate Halmahera Utara}

pengujian hipotesis variabel X dan Variabel Y menunjukan bahwa F sebesar 44.304 dengan tingkat signifikan sebesar 0.000 lebih kecil dari 0.05. Hal ini mengindikasi bahwa pemerintah Kabupaten Halamahera Utara telah mempunyai Penerapan Sistem pengendalian intern yang memadai dapat memaksimalkan pemanfaatan teknologi informasi. Penerapan Sistem pengendalian intern tersebut berupa pengendalian atas aplikasi. Pengendalian aplikasi dilakukan untuk memastikan bahwa tidak adanya kerusakan pada perangkat lunak dan keras dengan melakukan back up data ke komputer lain. Terkait hasil penelitian ini, responden sepakat bahwa jika Sistem Pengendalian Intern mampu mengoptimalkan pemanfataan teknologi dengan baik maka akan berdampak pada meningkatnya kualitas laporan keuangan pemerintah. Hasil ini sejalan dengan penelitian yang dilakukan oleh Sembiring (2013). Pegawai bagian pengelola keuangan di SKPD Kabupaten Halamahera Utara sudah memiliki kualifikasi yang memadai. Hal ini terlihat dari lama masa bekerja pegawainya yang mayoritas diatas 30 tahun. Berbagai pelatihan juga diikuti oleh para pegawai di bagian pengelolaan keuangan. Salah satu dari pelatihan tersebut adalah pelatihan dibidang penggunaan software aplikasi akuntansi yang dimiliki oleh masing-masing SKPD di Pemerintahan Kabupaten Halmahera Utara. Dengan adanya pelatihan dibidang Pemanfaatan Teknologi Informasi ini, maka dapat membantu staf sub bagian akuntansi agar dapat memproses serta mengolah data akuntansi menggunakan software yang disediakan sehingga proses pengolahan dan penyajian data akuntansi menjadi lebih cepat dan akurat.

Hal tersebut dapat meningkatkan kualitas pelaporan keuangan pemerintah daerah, Dimana metode manual yang biasa dipakai untuk mengolah dan menyusun laporan keuangan pemerintah, digantikan tugasnya oleh komputer yang memiliki kemampuan berkali-kali lipat lebih cepat dan akurat dibandingkan dengan dilakukan secara manual. Sistem pengendalian yang baik, akan mendukung sumber daya manusia dan teknologi informasi, Dimana sumber daya manusia yang mengolah data akuntansi akan mengetahui kualitas pelaporan keuangan pemerintah daerah. Apa saja yang harus dilakukan sesuai dengan sistem pengendalian yang disusun, sehingga dapat terhindar dari terjadinya penyimpangan-penyimpangan yang mungkin dilakukan. Selain itu, dengan adanya penerapan sistem pengendalian intern, potensi kerusakan komputer yang digunakan dapat diminimalisir karena ada langkah-langkah pencegahan untuk mengurangi potensi kerusakan dan terhentinya operasi computer, Sehingga komputer yang digunakan oleh pegawai bagian pengelolaan keuangan yang berkualitas serta didukung oleh penerapan sistem pengendalian intern yang baik, akan dapat menyelesaikan laporan keuangannya secara lebih cepat dan akurat sehingga dapat meningkatkan kualitas pelaporan keuangan pemerintah daerah.

\section{KESIMPULAN DAN SARAN}

\subsection{Kesimpulan}

Berdasarkan hasil penelitian dan pembahasan yang di lakukan sebelumnya, maka dari penelitian ini dapat kemukakan kesimpulan sebagai berikut:

1. Pemanfaatan teknologi informasi berpengaruh positif dan signifikan terhadap Kualitas Laporan Keuangan Pemerintah Daerah Kabupaten Halmahera Utara.

2. Penerapana Sistem Pengendalian Intern Pemerintah (SPIP) berpengaruh Positif dan signifikan terhadap Kualitas Laporan Keuangan Pemerintah Daerah Kabupaten Halmahera Utara. 


\subsection{Saran}

Berdasarkan hasil penelitian yang telah disimpulkan dan keterbatasan penelitian yang telah dijabarkan, selanjutnya dapat diusulkan saran yang diharapkan dapat bermanfaat bagi Kabupaten Halamahera Utara khusunya pada Satuan Keraja Perangkat Daerah (SKPD) sebagai objek penelitian ini diantara lain:

a. Diharapkan Di Kabupaten Halmahera Utara dapat meningkatkan kualifikasi pendidikan pegawainya dalam bidang akuntansi.

b. Diharapkan pemrintah daerah sering memberikan pelatihann - pelatihan yang berkaitan dengan keuangan dan akuntansi sehingga kapasitas sumber daya manusia dapat lebih ditingkatkan.

c. Lebih memaksimalkan penggunaan teknologi informasi agar laporan keuangan dapat disajikan tepat waktu.

\section{DAFTAR PUSTAKA}

Armando, Gerry. 2013. Pengaruh Sistem Pengendalian Intern Pemerintah dan Pengawasan Keuangan Daerah Terhadap Nilai Informasi Laporan Keuangan Pemerintah (Studi Empiris Pada Satuan Kerja Perangkat Daerah Di Kota Bukit tinggi). Jurnal. Fakultas Ekonomi. Universitas Negeri Padang. Vol 1, No 1 (2013) Hal 1-27

Ghozali Imam. 2013. Aplikasi Analisis Multivariate Dengan Program IBM SPSS 21.

Semarang : Badan penerbit Universitas Diponegoro

Mahmudi. 2016. Analisis Laporan Keuangan Pemerintah Daerah, Edisis Ketiga Yogyakarta: UUP STIM YKPN.

Nurmalia Hasanah dan Achmad Fauzi. 2016. Akuntansi Pemerintah. Jakarta: IN MEDIA.

Nuryanto Muh dan Nunuy N. Afiah. The Impact of Apparatus Competence, Information Technology Utilization and Internal Control on Financial Statement Quality (Study on Local Government of Jakarta Province - Indonesia) Woird Review of Business Researh Vol.3 No.4 Issue Hal 157-171.

Pramudiarta, Rizal. 2015. "Pengaruh Kompetensi Sumber Daya Manusia, Pemanfaatan Teknologi Informasi, dan Sistem Pengendalian Intern Terhadap Nilai Informasi Pelaporan Keuangan Entitas Akuntansi Pemerintah Daerah (Studi Persepsi Pegawai Skpd di Kabupaten Batang dan Kabupaten Kendal)". Skripsi, Universitas Diponegoro Semarang. Republik Indonesia, Undang- Undang Nomor 6 Tahun 2014 tentang Desa.

Reeve, M. Jame, Duchac Suhardianto, Kalanjati Jusuf, dan Djakman. 2012. Pengantar Akuntansi, Principles of Accounting, Buku I. Penerbit Salemba Empat, Jakarta Selatan.

Siregar, Baldric, 2015. Akuntansi Sektor Publik (Akuntansi Keuangan Pemerintah Daerah Berbasis Akrual), UPP STIM YKPN, Yogyakarta.

Syakur, Ahmad Syafi'1, 2015. .Intermediate Accounting Dalam Perspektif Lebih Luas. Edisi Revisi. Buku Pembuka Cakrawala, Jakarta.

Sutabri, Tatang. (2014). Pengantar Teknolo-gi Informasi. Yogyakarta: ANDI

Suwanda, Dadang. dan Dailibas. 2013. Panduan Penerapan Sistem Pengendalian Intern Pemerintah. Jakarta: PPM.

Suwanda. 2010. Peraturan Pemerintah No. 60 Tahun 2010 tentang Sistem Pengendalian Intern Pemerintah.

Suwanda. 2010. Peraturan Pemerintah No. 71 Tahun 2010 tentang Standar Akuntasi Keuangan 